\title{
Segmentasi Kerusakan Daun Padi pada Citra Digital
}

\author{
Khoerul Anwar" ${ }^{\# 1}$, Sigit Setyowibowo ${ }^{\# 2}$

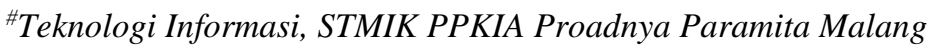 \\ Jl. LA Sucpto 249 A Malang \\ ${ }^{1}$ alqhoirestimata.ac.id \\ ${ }^{2}$ sigitestimata.ac.id
}

\begin{abstract}
Abstrak - Kerusakan daun padi menyebabkan produksi padi mengalami penurunan dan kerugian ekonomi terutama di bidang pertanian. Pada bidang visi komputer hal penting dalam mendeteksi kerusakan adalah melakukan segmentasi area daun yang rusak. Berbagai kajian tentang segmentasi area telah dilakukan oleh para peneliti sebelumnya. Namun pada penelitian ini dikaji tentang segmentasi otomatis. Pada penelitian ini bertujuan untuk mendapatkan warna citra yang menghasilkan segmentasi kerusakan pada daun padi terbaik. Penulis mengusulkan metode baru untuk segmentasi berdasarkan statistika nilai piksel citra daun padi sebagai alternatif dari metode yang sudah ada. Statistika nilai piksel untuk segmentasi yang digunakan adalah 0.20 dari nilai tertinggi masing-maisng komponen warna Hue, Saturation, Value $(0.20 *$ maks (HSV)). Metode yang diusulkan telah diujikan pada komponen warna Hue, Saturation, Value dan Grayscale. Hasil yang diperoleh dari pengujian menunjukkan bahwa komponen warna Hue sukses melakukan segmentasi, sementara komponen warna Saturation, Value dan pada citra dengan warna grayscale gagal melakukan segmentasi.
\end{abstract}

Kata kunci- Segmentasi, Thresold, Komponen Warna HSV, Grayscale, Daun Padi

\section{PENDAhUluaN}

Penyakit tanaman menyebabkan produksi dan kerugian ekonomi terutama di bidang pertanian. Penyakit ini sering menimbulkan gejala visual pada permukaan daun, seperti bintik-bintik, coretan, dan perubahan warna [1]. Identifikasi penyakit tersebut biasanya dilakukan secara konvensional dengan memeriksa fisik daun tanaman padi. Sementara itu memungkinkan identifikasi tersebut dilakukan dengan menggunakan perangkat teknologi digital, yaitu pemeriksaan gejala kerusakan pada daun dilakukan berdasarkan citra digital. Menjadi tantangan dalam hal ini adalah bagaimana teknologi digital mampu melokalisir gejala kerusakan tersebut dengan benar. Pada pengolahan citra digital pemisahan area gejala yang nampak dengan area bukan gejala pada permukaan daun diperlukan teknik melokalisir area gejala. Teknik ini dalam bidang penglahan citra dikenal sebagai teknik segmentasi.

Segmentasi citra sampai saat ini masih menjadi perhatian yang cukup penting dalam hal pengolahan citra digital. Segmentasi merujuk pada partisi [2] sebuah citra menjadi beberapa bagian yang didasarkan kemiripan ciri [3] atau keseragaman yang dimiliki [4]. Kegunaannya cukup penting khususnya terkait analisis dan aplikasi pengolahan citra digital. Ada beberapa metode yang efektif untuk segmentasi citra dalam bidang pertanian seperti threshold, clustering, area dan model [1]. Thresholding histogram [5] telah digunakan dalam analisis citra khususnya analisis data berdasarkan dua alasan utama: mampu menunjukkan secara solid untuk data yang cukup besar dan memungkinkan digunakan untuk menyimpulkan ciri dari perilaku data dalam histogram. Sebuah ciri mampu dijelaskan dengan baik pada bidang 1-D [6] dengan cara yang cukup sederhana. Setiap ciri memiliki interval nilai yang berbeda satu dengan lainnya. Hal itu ditunjukkan oleh tiap ciri memiliki nilai puncak yang berbeda dan pada jarak tertentu. Berdasarkan ciri tersebut citra dapat disegmentasi dengan baik.

Segmentasi menggunakan thresholding warna [2] dituliskan bahwa segmentasi berdasarkan warna sangat efektif untuk mengetahui tingkat kematangan buah dan sayur tanpa kesulitan dengan mengubah sebagian nilai parameternya. Pada [7] dilaporkan analisis pendekatan segmentasi kulit dengan menggunakan klasifikasi piksel warna. Pengklasifikasi Bayesian dengan teknik histogram dan pengklasifikasi perceptron multilayer ditemukan memiliki tingkat klasifikasi yang lebih tinggi dibandingkan dengan pengklasifikasi yang diuji lainnya. thresholding histogram [5] menuliskan Aspek statistik dari pendekatan ini membuatnya kuat terhadap noise kuantisasi: semakin besar jumlah sampel, semakin banyak histogram yang dapat dianggap deterministik dan semakin tersegmentasi. Telah diperoleh hasil segmentasi dengan menggunkan histogram warna secara hierarki di ruang HSV. Sementara itu [8] menggunakan nilai rentang piksel atau nilai threshold global dan lokal untuk diklasifikasikan. Metode thresholding global hanya memilih satu nilai ambang batas untuk keseluruhan citra. Thresholding lokal memilih nilai ambang batas yang berbeda untuk wilayah yang berbeda. Untuk melakukan segmentasi gambar yang kompleks, thresholding multilevel diperlukan. Kesemuanya itu bertujuan untuk memisahkan antara background dan 
foreground. Tantangan yang dihadapi adalah tidak ada sebuah metode segmentasi yang mampu digunakan untuk semua kasus. Hal ini disebabkan citra memiliki perbedaan dalam bentuk warna, teksture, tingkat iluminasi dan noise yang berbeda.

\section{Metode Penelitian}

Pada penelitian ini penulis mengusulkan metode baru untuk segmentasi kerusakan daun padi berdasarkan statistika nilai piksel citra daun padi sebagai alternatif dari metode yang sudah ada. Adapun alur kerja dari metode yang diusulkan tersebut ditunjukkan pada gambar. 1 .

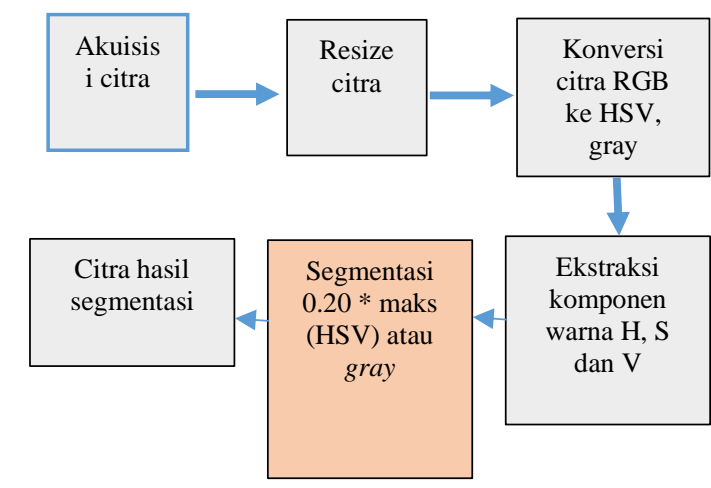

Gambar. 1 Diagram alur sistem

\section{A. Akuisisi Citra}

Segmentasi penyakit daun padi yang diakibatkan oleh serangan perusak daun secara visual sangat membantu proses identifikasi jenis penyakit daun. Metode ini dapat digunakan untuk mengetahui kerusakan daun padi dengan bantuan citra sehingga analisis kerusakan dapat dilakukan berdasarkan citra. Teknik ini dapat digunakan oleh para petani atau pengguna lainnya yang memiliki sedikit pengetahuan tentang penyerang daun padi.

Database citra daun padi diperoleh dari akuisi dengan menggunakan kamera smart phone Samsung Galaxy A5. Level pencahayaan untuk mendapatkan citra daun padi adalah cahaya normal sinar matahari dan tanpa bantuan flash. Dataset citra daun padi terdiri dua variasi utama: potongan daun saja, dan daun pada tumbuhan padi. Resolusi citra 5 mega piksel. Sementara citra juga didapat dari download di internet. Kemudian untuk setiap citra dinormalisasi pada resolusi 255 x 355 piksel. Contoh citra daun padi yang terindikasi terserang penyakit ditunjukkan pada Gambar. 2.

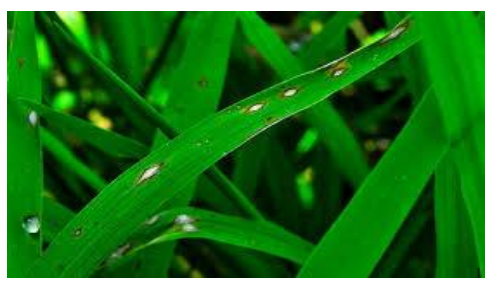

Gambar. 2. Daun padi mengalami kerusakan

\section{B. Metode Yang Diusulkan}

Metode yang diusulkan dalam makalah ini adalah teknik untuk melokalisir background dan foreground. Metode ini dibangun dengan menentukan perbedaan antara latar belakang dan daerah yang rusak, selanjutnya nilai ambang batas antara background dan foreground yang di pilih secara otomatis. Perbedaan antara foreground dan background dapat dianalisis berdasarkan perbedaan warna yang muncul pada citra. Secara umum warna daun padi adalah hijau untuk tanaman yang sedang dalam masa pertumbuhan. Sementara warna daun padi yang rusak cenderung berwarna kecoklatan. Nilai piksel warna hijau dan coklat perbedaannya cukup jauh. Perbedaan inilah yang digunakan untuk melokalisir antara foreground dan background yang diinginkan. Foreground sebagai area yang diduga mengalami kerusakan pada daun dan background adalah area daun yang tidak mengalami kerusakan. Beberapa teknik yang telah digunakan untuk identifikasi atau segmentasi kerusakan pada daun diantaranya K-mean clusstering [9],[10],[11], otsu [12], convolution neural network [13]. Sementara [14] menggunakan teknik ekstraksi ciri daun untuk identifikasi kerusakan pada daun. Segmentasi dilakukan dengan beberapa fitur (adaptive or dynamic, otsu, k-means) dilakukan oleh [15].

Pada paper ini di gunakan warna HSV (Hue, Saturation, Value) untuk pemrosesan awal dan kemudian komponen warna diekstraksi menjadi $\mathrm{H}, \mathrm{S}$ dan $\mathrm{V}$. Pada citra dengan warna HSV perbedaan di antara background dan foreground terlihat lebih jelas.

Perhitungan nilai piksel komponen citra HSV diperoleh dari nilai piksel citra RGB (reed, green, blue). Nilai $R, G, B$ dalam besaran rentang nilai 1 sampai 255 dirubah menjadi nilai 0.0 sampai 1 untuk citra $\mathrm{H}, \mathrm{S}, \mathrm{V}$. Nilai 0.01 mereferensikan warna gelap dan nilai 1 untuk terang. Perhitungan piksel menggunakan persamaan 1:

$$
\begin{aligned}
& R^{\prime}=R / 255 \\
& G^{\prime}=G / 255 \\
& B^{\prime}=B / 255 \\
& C \max =\max \left(R^{\prime}, G^{\prime}, B^{\prime}\right) \\
& C \min =\min \left(R^{\prime}, G^{\prime}, B^{\prime}\right) \\
& \Delta=C \max -C \min
\end{aligned}
$$

Kemudian dihitung masing-masing nilai komponen HSV, untuk:

1) Formula Hue $(H)$ : Formual perhitungan nilai piksel Hue menggunakan persamaan 2:

$$
H=\left\{\begin{array}{cc}
0^{\circ} & \Delta=0 \\
60^{\circ} \times\left(\frac{G^{\prime}-B^{\prime}}{\Delta} \bmod 6\right) & , C_{\max }=R^{\prime} \\
60^{\circ} \times\left(\frac{B^{\prime}-R^{\prime}}{R^{\Delta}}+2\right) & , C_{\max }=G^{\prime} \\
60^{\circ} \times\left(\frac{R^{\prime}-G^{\prime}}{\Delta}+4\right) & , C_{\max }=B^{\prime}
\end{array}\right.
$$

2) Formula Saturation (S) : Formula perhitungan nilai piksel Hue menggunakan persamaan 3: 


$$
S=\left\{\begin{array}{cc}
0 & , C_{\max }=0 \\
\frac{\Delta}{C_{\max }} & , C_{\max } \neq 0
\end{array}\right.
$$

3) Formula Value (V): Formula perhitungan nilai piksel Hue menggunakan persamaan 4:

$$
\mathrm{V}=\mathrm{Cmax}
$$

Setelah proses ekstraksi komponen warna citra dan diperoleh nilai piksel komponen $\mathrm{H}$, S, dan V yang masingmasing dalam bentuk matrik, maka proses selanjutnya adalah merubah matrik tersebut menjadi bentuk vektor (array). Pada penelitian ini bentuk matrik seperti dituliskan pada persamaan 5, sementara bentuk vektor ditunjukkan pada persamaan 6:

4) Matrik Nilai Piksel Komponen H: Matrik nilai piksel komponen $\mathrm{H}$ dituliskan dengan menggunakan persamaan 5:

$$
\mathrm{H}=\left[\begin{array}{ll}
c_{11} & c_{21} \\
c_{12} & c_{22} \\
c_{13} & c_{n m}
\end{array}\right]
$$

5) Vektor Nilai Piksel Komponen $H$ : Nilai $\mathrm{H}$ digunakan untuk membuat histogram citra. Kemudian dari hitogram ini dilakukan analisis nilai forgraund untuk memperoleh nilai threshold. Bentk vektor seperti tertulis pada persamaan 6:

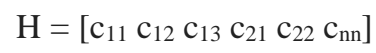

6) Nilai Threshold: Nilai threshold diperoleh dari analisis nilai piksel komponen HSV. Citra daun padi dengan komponen $\mathrm{H}$ menunjukkan untuk foreground adalah warna gelap dan background adalah warna terang. Pada penelitian ini nilai threshold didasarkan pada proses eksperimen pendahuluan dan diperoleh nilai 0.20 dari nilai tertinggi piksel citra HSV dan Gray. Hasil eksperimen formula threshold yang digunakan seperti tertulis pada persamaan 7:

$$
\text { Thrs }=0.20 * \operatorname{maks}(\mathrm{H})
$$

Persamaan 7 diperoleh dari analisis nilai piksel foreground untuk beberapa daun pada area yang teridentifikasi mengalami kerusakan.

7) Segmentasi Area Cacat Daun: Segmentasi dilakukan dengan menggunakan metode binerisasi warna citra. Nilai 1 untuk warna cacat daun dan 0 untuk warna daun sehat. Memperhatikan persamaan 5 dan 7 maka segmentasi dilakukan dengan logika sebagai berikut

Jika $H(i, j)>$ thrs, SegDaun $(i, j)=0$;

Selain itu SegDaun $(i, j)=1$;

Berakhir

$\mathrm{H}(\mathrm{i}, \mathrm{j})$ adalah matrik piksel komponen warna citra $\mathrm{H}$, sementara SegDaun $(i, j)$ adalah citra hasil segmentasi.
8) Algoritme: Adapun algoritme yang dibagun untuk segmentasi adalah sebagai berikut;

- RGB dikonversi ke HSVs

- Ekstraksi nilai HSV

- Pilih warna komponen HSV

- Konversi matrik $\mathrm{H}_{\mathrm{m} \times \mathrm{n}}$ menjadi vector $\mathrm{H}_{1 \times \mathrm{n}}$

- Menentukan nilai ambang batas $->\mathrm{sthr}=0.20 *$ maks $(\mathrm{H}(:))$

- Segmentasi

- Selesai

\section{HASIL DAN PEMBAHASAN}

Pengujian metode yang diusulkan telah dilakukan pada citra daun padi dengan tingkat kerusakan yang sederhana (pada lokasi khusus) sampai jenis citra dengan tingkat kerusakan yang komplek (menyebar). Uji coba pertama dilakukan pada komponen warna $\mathrm{H}$ dengan hasil seperti ditunjukkan oleh Gambar. 3.

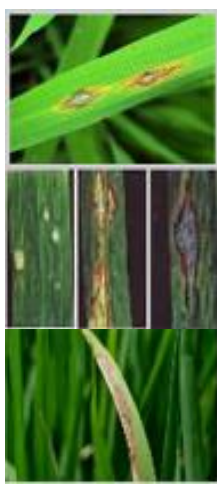

(a)

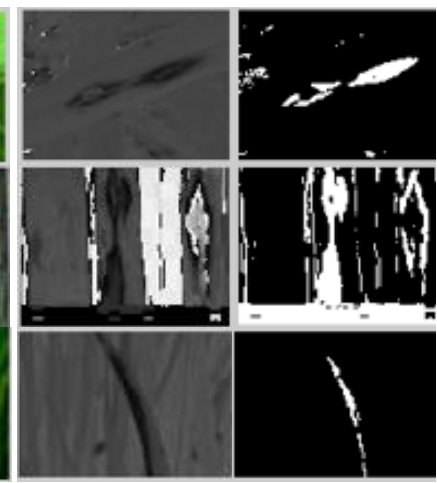

(b)

(c)
Gambar. 3 Hasil segmentasi hue: (a) citra RGB, (b) citra hue, dan (c) cita tersegmentasi

Hasil pengujian seperti ditunjukkan pada Gambar. 3 untuk baris pertama dengan citra uji yang terindikasi kerusakan pada daun relatif sederhana. Metode yang diajukan dapat melakukan segmentasi area kerusakan. Pada pengujian yang kedua dengan kerusakan citra yang relatif lebih parah. Citra ini memuat tiga helai daun padi. Hasil pengujian seperti ditunjukkan oleh citra pada baris kedua yang mengindikasikan metode yang ditawarkan mampu mengenali area kerusakan dengan baik. Demikian juga pada hasil pengujian ke tiga, metode yang ditawarkan mampu melakukan segmentasi dengan baik. 


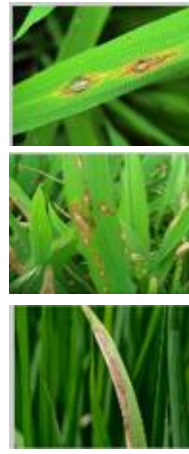

(a)
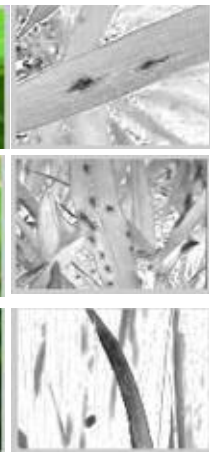

(b)
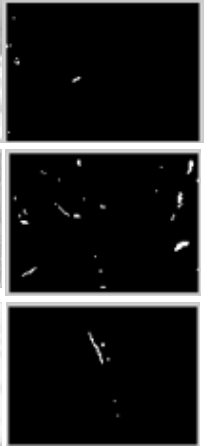

(c)
Gambar. 4 Hasil segmentasi saturation: (a). citra RGB, (b) citra Saturation, dan (c) citra tersegmentasi

Pengujian metode yang diusulkan pada komponen warna Saturation (S) dengan hasil seperti yang ditunjukkan pada Gambar. 4 dilakukan menggunakan nilai ambang batas dengan berdasar pada persamaan 7, yakni $0.20 *$ maks (komponen). Analisis hasil pengujian terhadap Gambar.4 dijelaskan sebagai berikut: baris pertama dengan citra uji yang terindikasi kerusakan pada daun relatif sederhana. Hasil pengujian menunjukkan bahwa metode yang ditawarkan kesulitan melakukan segmentasi area kerusakan daun. Pada pengujian yang kedua dengan kerusakan citra yang relatif komplek. Hasil pengujian seperti ditunjukkan oleh citra pada baris kedua yang mengindikasikan metode yang ditawarkan kesulitan mengenali area kerusakan dengan baik. Demikian juga pada hasil pengujian ke tiga, metode yang ditawarkan juga belum mampu melakukan segmentasi dengan baik

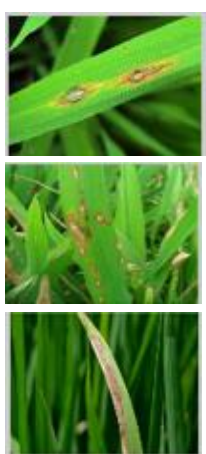

(a)
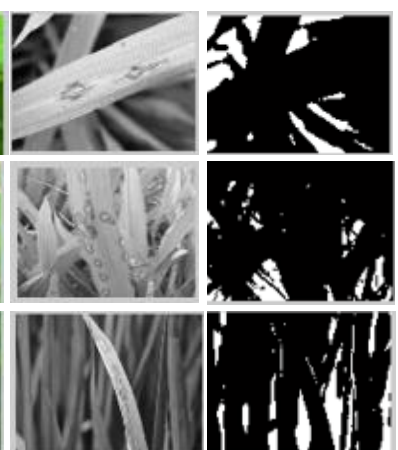

(b)

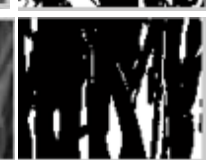

(c)
Gambar. 5 Hasil segmentasi value: (a). citra RGB, (b) citra value, dan (c) citra tersegmentasi

Pengujian metode yang diusulkan pada komponen warna value (V) dengan hasil seperti ditunjukkan pada Gambar. 5 Pengujian yang telah dilakukan pada citra yang relatif sederhana seperti pada baris pertama metode segmentasi yang ditawarkan tidak berkerja dengan baik. Pada citra value area yang terindikasi kerusakan dengan background memiliki perbedaan nilai yang relatif kecil.

Sehingga hasil segmentasi tidak menunjukkan kinerja dengan maksimal. Demikian juga pengujian pada citra dengan area kerusakan daun yang lebih komplek, metode yang ditawarkan juga tidak bekerja dengan maksimal. Pada citra uji ke dua, citra foreground dan background perbedaan warna tidak berbeda secara tajam. Oleh karena metode segmentasi yang ditawarkan tidak mampu bekerja secara optimal. Demikian juga pada hasil pengujian ke tiga, metode yang ditawarkan tidak mampu melakukan segmentasi dengan baik.

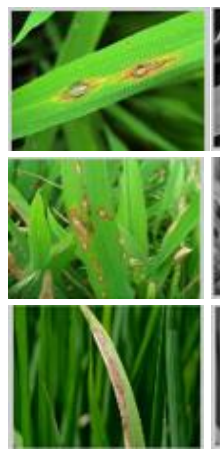

(a)

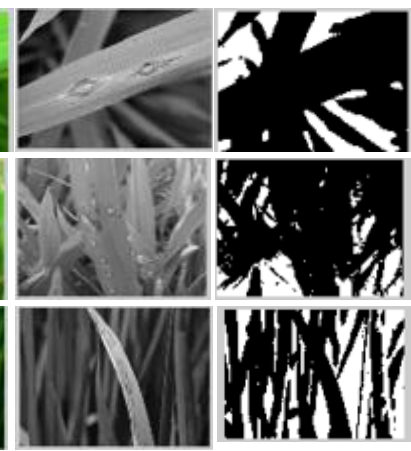

(b) (c)
Gambar. 6 Hasil segmentasi gray: (a). citra RGB, (b) citra gray, dan (c) citra tersegmentasi

Pengujian metode yang diusulkan pada citra warna grayscale. Hasil pengujian seperti ditunjukkan pada Gambar 6. Baris pertama dengan citra uji grayscale, diperlihatkan bahwa warna area kerusakan dan warna daun yang sehat tidak terlalu berbeda secara signifikan. Oleh karena itu metode yang ditawarkan mengalami kesulitan untuk segmentasi dengan baik. Pada pengujian yang kedua dengan kerusakan citra yang relatif lebih parah. Citra gray menunjukkan area kerusakan tidak terlihat secara kuat, sehingga hasil segmentasi tidak terlihat dengan baik. Demikian juga pada hasil pengujian ke tiga, metode yang ditawarkan tidak mampu melakukan segmentasi dengan baik.

TABEL I

HASIL SEGMENTASI PADA CITRA

\begin{tabular}{|c|l|l|c|c|c|}
\hline No & Citra Uji & Hue & $\begin{array}{l}\text { Satura- } \\
\text { tion }\end{array}$ & Value & Gray \\
\hline 1 & sukses & gagal & gagal & gagal \\
\hline 2 & & sukses & gagal & gagal & gagal \\
\hline 3 & & sukses & gagal & gagal & gagal \\
\hline
\end{tabular}

Pada Tabel. 1 dituliskan hasil eksperimen metode yang diusulkan terhadap komponen warna citra yaitu Hue, Saturation, Value dan Gray untuk segmentasi kerusakan pada daun padi. Hasil yang diperoleh menunjukkan komponen warna citra Hue sukses melakukan segmentasi kerusakan daun padi sementara komponen citra Saturation, Value dan Gray gagal melakukan segmentasi. 


\section{KESIMPULAN}

Metode yang diusulkan mampu menunjukkan komponen warna citra Hue sebagai komponen warna terbaik untuk segmentasi kerusakan pada daun padi. Metode yang diusulkan memperlihatkan komponen warna Hue dapat menampilkan citra foreground dan background dengan jelas. Sehingga segmentasi dengan komponen warna Hue lebih sukses dibandingkan penggunaan komponen warna Saturation, Value dan juga citra warna grayscale.

\section{REFERENSI}

[1] Q. Hu, J. Tian, and D. He, "Wheat leaf lesion color image segmentation with improved multichannel selection based on the Chan - Vese model," Comput. Electron. Agric., vol. 135, pp. 260268, 2017, doi: 10.1016/j.compag.2017.01.016.

[2] M. Dadwal and V. K. Banga, "Color Image Segmentation for Fruit Ripeness Detection: A Review,"pp. 190-193, 2012.

[3] S. Dutta and B. B. Chaudhuri, "Homogenous Region based Color Image Segmentation," vol. II, 2009.

[4] N. Ikonomakis, K. N. Plataniotis, and A. N. Venetsanopoulos, "Color Image Segmentation for Multimedia Applications," pp. 520, 2000.

[5] J. Delon, A. Desolneux, J. Lisani, and A. B. Petro, "A Nonparametric Approach for Histogram Segmentation," vol. 16, no.
1, pp. 253-261, 2007.

[6] J. Delon, A. Desolneux, J. L. Lisani, and A. B. Petro, "Color Image Segmentation Using Acceptable Histogram Segmentation," pp. 239-246, 2005.

[7] S. L. Phung, "Skin segmentation using color pixel classification: analysis and comparison," vol. 27, no. January, pp. 148-154, 2005.

[8] N. Sharma, M. Mishra, and M. Shrivastava, "Colour Image Segmentation Techniques And Issues : An Approach," vol. 1, no. 4, pp. 9-12, 2012.

[9] S. Maity et al., "Fault Area Detection in Leaf Diseases using kmeans Clustering."

[10] D. Albashish and S. Bani-ahmad, "Detection and Classification of Leaf Diseases using K-means-based Segmentation and Neuralnetworks-based Classification," no. February, 2011, doi: 10.3923/itj.2011.267.275.

[11] J. Baghel and P. Jain, "K-Means Segmentation Method for Automatic Leaf Disease Detection,” vol. 6, no. 3, pp. 83-86, 2016.

[12] P. Chaudhary, A. K. Chaudhari, and S. Godara, "Color Transform Based Approach for Disease Spot Detection on Plant Leaf," vol. 3, no. 6, pp. 4-9, 2012.

[13] Z. Wang and S. Zhang, "Segmentation of Corn Leaf Disease Based on Fully Convolution Neural Network," vol. 1, no. 1, pp. 9-18, doi: 10.25236/AJCIS.010002.

[14] S. Yun, W. Xianfeng, Z. Shanwen, and Z. Chuanlei, "PNN based crop disease recognition with leaf image features and meteorological data," vol. 8, no. 4, pp. 60-68, 2015, doi: 10.3965/j.ijabe.20150804.1719.

[15] A. Ams, "An Analysis Of Segmentation Techniques," no. November, 2018, doi: 10.13140/RG.2.2.25054.08002. 